\title{
Effectiveness of Improved Hermetic Storage Structures Against Maize Storage Insect Pests Sitophilus zeamais and Prostephanus truncatus
}

\author{
Tadele Tefera ${ }^{1}$, Addis Teshome ${ }^{2} \&$ Charles Singano ${ }^{3}$ \\ ${ }^{1}$ International Centre of Insect Physiology and Ecology (ICIPE), ILRI Campus, Addis Ababa, Ethiopia \\ ${ }^{2}$ Swiss Agency for Development and Cooperation (SDC), Addis Ababa, Ethiopia \\ ${ }^{3}$ Chitdze Research Station, Department of Agricultural Research Services, Lilongwe, Malawi \\ Correspondence: Tadele Tefera, International Center of Insect Physiology and Ecology (ICIPE), ILRI Campus, \\ Gurd Shola, P.O. Box 5689, Addis Ababa, Ethiopia. Tel: 251-944-168-240. E-mail: ttefera@icipe.org
}

Received: April 16, 2018

doi:10.5539/jas.v10n8p100
Accepted: May 19, $2018 \quad$ Online Published: July 15, 2018

URL: https://doi.org/10.5539/jas.v10n8p100

\begin{abstract}
A study was conducted for 12 months to evaluate the effectiveness of two improved hermetic storage structures against two maize storage pests Sitophilus zeamais and Prostephanus truncatus at Liwufu Research Station, Malawi. The storages were metal silo and hermetic bag; Actellic super dust was included as a control. The treatments (storages) were replicated four times under natural and artificial infestations. Grain stored in metal silo had the lowest mean percentage weight loss, $1.04 \%$ to $1.25 \%, 12$ months after storage followed by hermetic bag, $2.46 \%$ to $6.64 \%$. Grain treated with Actellic super had the highest weight loss, $4.86 \%$ to $18.72 \%$. The study showed that hermetic storage structures can be promoted as effective alternative non-chemical methods of grain storage for small holder farmers in Malawi.
\end{abstract}

Keywords: maize, Malawi, metal silo, post-harvest losses, hermetic bag

\section{Introduction}

Malawi's economy is heavily dependent on agriculture which employs about $85 \%$ of the population, contributes $38 \%$ of Gross Domestic Product (GDP), as well as 90\% foreign exchange earnings (IFPRI, 2013). Maize is the dominant subsistence crop and the main staple food in Malawi and is grown by $97 \%$ of farming households (Bezu et al., 2013). This staple grain crop plays a crucial role for food security, income generation, as well as the livelihoods of rural inhabitants in Malawi (Maonga et al., 2015). Almost all maize is grown on rain-fed production that is not sufficient to meet household consumption needs. As a result, the average months of food security for rural households from their own production in a normal year is between six and seven months (Aberman et al., 2015). Low yield, stagnating productivity growth and low input use by small holder farmers have contributed to poor performance of the agricultural sector and low productivity in maize. These factors coupled with significant post harvest losses will undoubtedly endanger household food security for majority of rural farmers (Aberman et al., 2015).

Malawi has adopted scaling up a large inorganic fertilizer and improved maize seed subsidy programs in 2005 and 2006 respectively (Blessings, 2012) which resulted in surplus production and achieving food security in the country. However, the potential impact of such food security and input subsidy programs on poverty reduction and greater livelihood security will not be realized unless farmers are able to store grains and sell surplus production at attractive prices (Tefera et al., 2011). Hence, long term storage plays a significant role to even out fluctuations in production and market supply by taking produce off the market in surplus seasons, and releasing it back onto the market in lean seasons (Proctor, 1994). Destructive storage pests such as the maize weevil (Sitophilus zeamais) and larger grain borer (LGB) (Postephanus truncatus) affect the quantity and quality of stored grains (Kimenju \& De Groote, 2010). World Bank report (2010) also showed that post-harvest storage losses in Southern Africa are predominately caused by moulds, rodents, and insect pests.

Studies on the level of postharvest losses indicate that more than $70 \%$ of maize stored on the cob is severely damaged by P. truncatus and other associated grain pests after 6 to 8 months of storage (Phiri \& Otieno, 2008). The cardinal problems are inadequate extension and marketing services, lack of adequate storage facilities due to combination of insufficient supply of appropriate technology and, where they exist, lack of credit or own capital 
for smallholder farmers to acquire them (FAO, 2010). Farmers have always been struggling to reduce losses in storage with the knowledge and resources they have in the past. However, improving smallholder maize storage practices have become increasingly more important over the past few decades since the introduction of the LGB in Africa (Rees et al., 2002).

Chemical insecticides such as Actellic super and Shumba super dusts have been promoted as effective pest management options against storage pests in most places in Malawi (Farrell \& Schulten, 2002). Traditional storage structures made of mud and twigs are also common in Malawi which are relatively inexpensive but often expose the stored maize to harsh environmental conditions such as sun and rain (Olakojo \& Akinlosotu, 2004). Other recently developed non-chemical methods of grain storage include metal silos and hermetic bags. Metal silos is a simple cylindrical structure made up of galvanized iron sheets and could store grain for more than one season without loss allowing farmers the freedom on when to sell their grain (Tefera et al., 2011; SDC, 2008). Hermetic bags are tougher polyethylene, able to maintain grain quality and quantity for prolonged period of times (Likayo et al., 2016; De Groote et al., 2013). Both metals silo and hermetic bags, they are portable, do not require pesticide application and can easily lock out insect pests and rodent. They also provide additional protection from theft in rural areas as they should be kept indoors unlike most traditional granaries which are usually constructed outdoors (Tefera et al., 2011). Hence, promotion of such improved post harvest management technologies has a positive and significant effect not only on ensuring food security but also farmer adoption of improved seed and the area that households plant to improved maize. This study, therefore, was conducted to determine the effectiveness of two improved hermetic storage technologies; viz., metal silo and hermetic bag, in reducing damage and loss caused by storage insects under two infestation methods in Malawi.

\section{Materials and Methods}

\subsection{Insects and Maize Grain}

Maize grain used for this study was purchased from a local market immediately during harvest. Sufficient number of $S$. zeamais and P. truncatus adults were obtained from postharvest insect pest laboratory at Chitedze Research Station reared on maize grain under $26 \pm 1^{\circ} \mathrm{C}$ and $65 \pm 3$ relative humidity.

\subsection{Description of the Storage Structures}

The metal silo, $100 \mathrm{Kg}$ holding capacity, was fabricated by trained local tinsmith from galvanized iron sheet (gauge No. 24) with a top loading inlet and a lateral unloading spout at the bottom (Likhayo et al., 2016) and hermetically sealed with rubber band. The Hermetic bag made of tougher polyethylene, inner liner, $78 \mathrm{~mm}$ thick, with good gas and water barrier, provided by MashAgric PLC, South Africa.

\subsection{Treatments and Experimental Set up}

The trial was conducted at Lifuwu Research Station (110 Km east of Lilongwe City) from December 2012 to January 2014. There were two improved storage structures evaluated in the present study. These were metals silo and hermetic bag (HB). Grain treated with Actellic Super (AS), stored in polypropylene bag (PPB), was included as a local farmers' practice. Metal silos were filled with $100 \mathrm{Kg}$ grain while the $\mathrm{HB}$ and Polypropylene bags treated with insecticide Actellic Super were filled with $40 \mathrm{Kg}$ of maize. The storage structures were subjected to two infestation methods: artificial and natural infestations. For artificial infestation, grains in all containers were infested with $S$. zeamais and $P$. truncatus in the ratio of 1 insect to $1 \mathrm{~kg}$ of maize regardless of the insect species, while for natural infestation, treatments were left to natural infestations. Maize grain used for artificial infestation fumigated using phosphine at the rate of $1.5 \mathrm{~g} / \mathrm{m}^{3}$ for 7 days; however, maize grain used for natural infestation was not fumigated. After filling the metal silos with grains, insects were introduced as stated above, a candle was lit in each silo; both the inlet and outlet of the silos were sealed using rubber bands. The HB were squeezed to remove air within the bags before loading and was sealed. As recommended, the HB were placed inside polypropylene bags to provide support and handling convenience. All storage structures were replicated three times in a randomized block design, placed on wood pallets in a warehouse.

\subsection{Sampling and Sample Analysis}

Grain sampling was done every 30 days. Samplings were done from the same storage structures every 30 days to reflect the farmers' practices. At each assessment, the storage structures were opened on top and $0.5 \mathrm{Kg}$ samples were collected using multi-compartment sampling spear. For the metal silo, each sampling was followed by introduction of a burning candle and closing tightly with a rubber band. The contents of the samples were then separated into grains, insects and dust using 4.7 and $1.0 \mathrm{~mm}$ sieves. Samples were analysed for the number of live and dead insects, number and weight of damaged and undamaged kernels and weight of the dust produced. Dust produced due to insect feeding and damaged and undamaged grains were weighed on a precision electronic 
scale. To estimate the percentage weight loss, collected samples were assessed by the 'count and weigh' method. Sampled grains were separated into damaged and undamaged, weighed, numbers counted and percentage weight losses for each sample were determined as follows (Adams and Schulter, 1978):

$$
\text { Weight } l o s s \%=\frac{(W u \times N d)-(W d \times N u)}{W u \times(N d+N u)} \times 100
$$

Where, $W u$ : weight of undamaged grain, $N u$ : number of undamaged grain, $W d$ : Weight of damaged kernel and $N d$ : Number of damaged kernels.

The percentage of insect damaged grains was calculated as:

$$
\text { Percent grain damaged }=\frac{\text { Number of Damaged Grains }}{\text { Total Number of Grains }} \times 100
$$

For percentage germination, randomly selected 100 grains from the samples were put in Petri dishes lined with moist filter paper and incubated for 7 days at ambient conditions, after which germinated (with first shot and roots) and non-germinated (with no or deformed first shots and roots) seeds were recorded. The rate of germination was calculated as a percentage of number of grains germinated to total number of grains.

\subsection{Data Analysis}

Data on number of insects were log-transformed $\left(\log _{10}\right)$, while percentage grain damage and weight loss were angular transformed (arcsine $\sqrt{\text { proportion})}$ in order to stabilize the variance. One-way analysis of variance (ANOVA) test was performed on transformed values using statistical software package SAS (SAS Institute, 2010). The Tukey HSD test was used to separate the means and means are significantly different when $P \leq 0.05$.

\section{Results}

\subsection{Weight Loss and Grain Damage}

There were significant differences $(\mathrm{P}<0.001)$ among the treatments under the two infestation methods for mean percentage weight loss and grain damage 12 months after storage (Table 1). Grain kept in metal silo had the least weight loss and damage followed by grain kept in HB. Grains treated with Actelic Super kept in PPB had suffered the highest weight loss and damage (Table 1). The highest mean percentage weight loss recorded for grains treated with Actellic Super and kept in PPB was 18.7\% with corresponding 41.6\% damage under artificial infestation.

Table 1. Mean percentage weight loss and grain damage in maize stored for 12 months in metal silo, hermetic bag and maize treated with actelic dust under natural and artificial infestation with Sitophilus zeamais and Prostephanus truncatus in Malawi

\begin{tabular}{llllll}
\hline \multirow{2}{*}{ Treatments } & \multicolumn{2}{c}{ Natural infestation } & & \multicolumn{2}{c}{ Artificial infestation } \\
\cline { 2 - 3 } \cline { 6 - 6 } \cline { 5 - 6 } & Weight loss (\%) & Grain damage (\%) & & Weight loss (\%) & Grain damage (\%) \\
\hline Metal silo & $1.25^{\mathrm{c}}$ & $10.40^{\mathrm{b}}$ & & $1.04^{\mathrm{c}}$ & $15.56^{\mathrm{c}}$ \\
Hermetic bag & $2.46^{\mathrm{b}}$ & $15.24^{\mathrm{ab}}$ & & $6.64^{\mathrm{b}}$ & $28.61^{\mathrm{b}}$ \\
Actellic Super & $4.86^{\mathrm{a}}$ & $18.53^{\mathrm{a}}$ & & $18.72^{\mathrm{a}}$ & $41.60^{\mathrm{a}}$ \\
SE & 1.33 & 1.88 & & 1.89 & 1.89 \\
\hline
\end{tabular}

Note. Means followed by the same letter in a column are not significantly different $(\mathrm{P}<0.05)$.

There was an increasing pattern in weight loss and damage over the storage time (Figures 1a-1d) under the two infestation methods. The metal silo kept the grain safe for 180 days after storage; however, there was a slow increase in weight loss 180 days after storage but it was remained below 5\% during the 360 days storage period under artificial infestation (Figure 1a). Grain treated with Actelic Super and kept in PPB had shown a sharp rise in weight loss 150 days after storage and the loss reached about $70 \%, 360$ days after storage. Under natural infestation, a sharp rise in weight loss and damage observed more in grain kept in PPB than in metal silo and HB, 210 days after storage (Figure $1 \mathrm{~b}$ and $1 \mathrm{~d}$ ). 


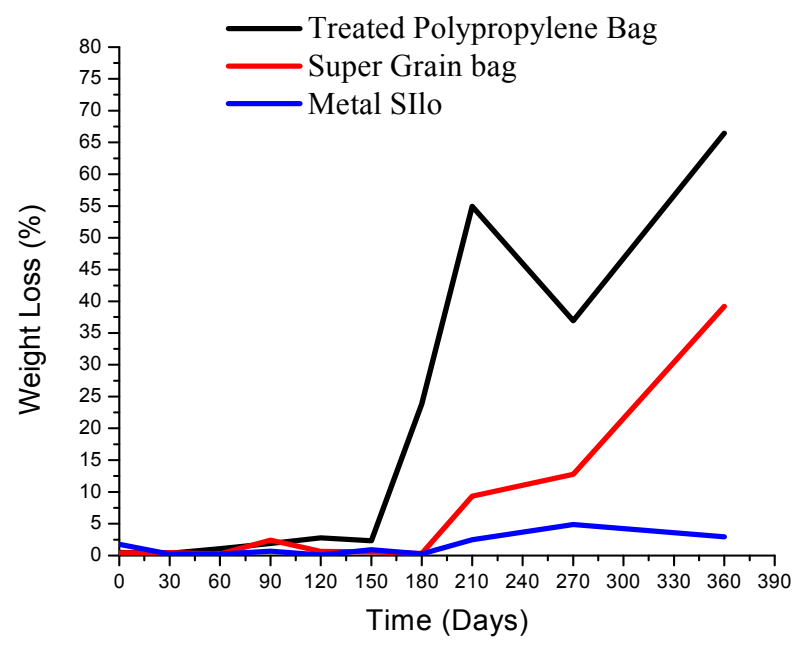

(a) Weight loss under artificial infestation

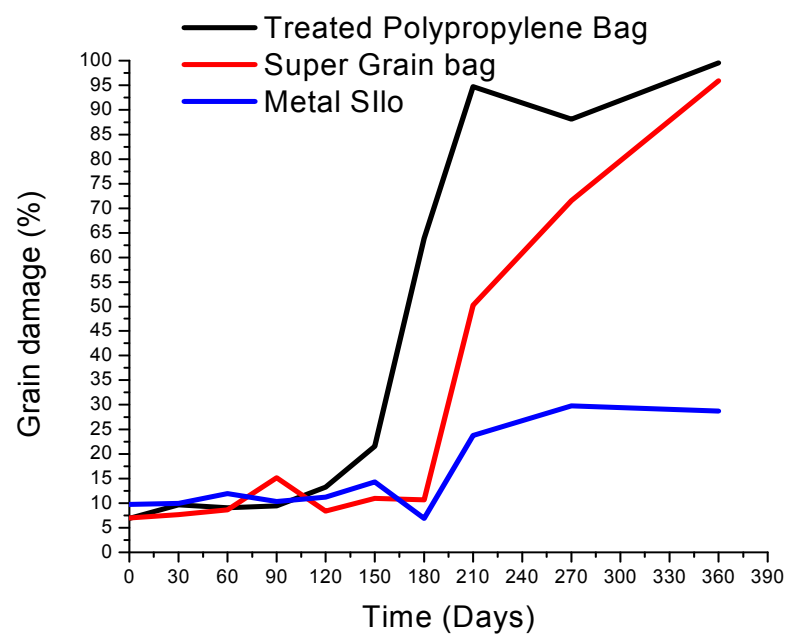

(c) Grain damage under artificial infestation

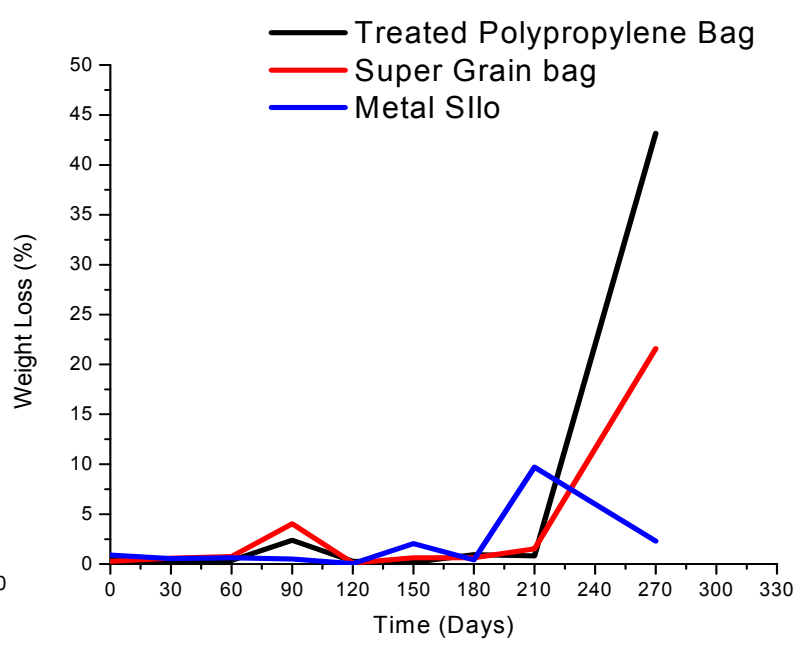

(b) Weight loss under natural infestation

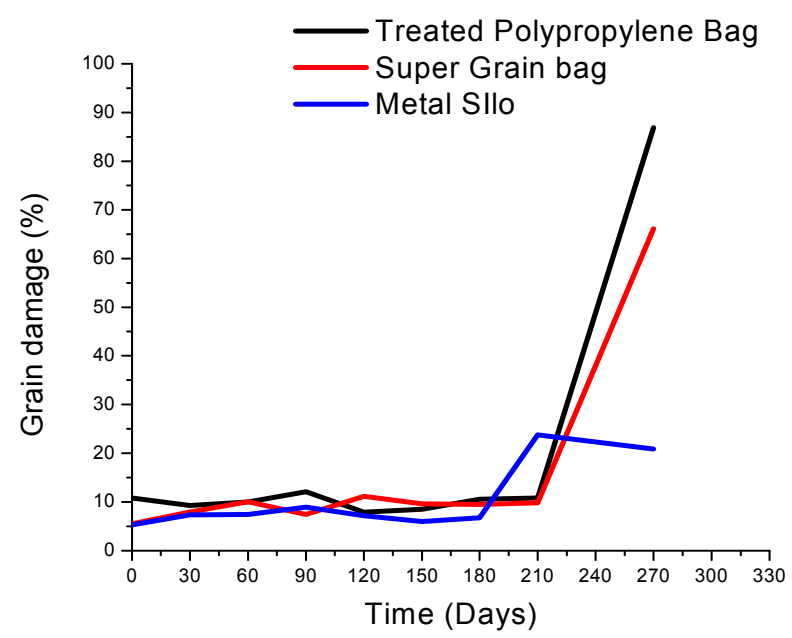

(d) Grain damage under natural infestation

Figure 1. Percentage weight loss under artificial (a) and natural (b) infestations, and grain damage under artificial

(c) and natural (d) infestations with Sitophilus zeamais and Prostephanus truncatus in maize stored for 12 months in Malawi

\subsection{Germination}

The initial germination for the grain used in this experiment was around $80 \%$. Slight decline in the rate of germination started 90 days after storage in all treatments. Sharp decline in germination started 50 days after storage for Actellic super while grain stored in metal silo retained germination longer with minimal progressive decline. The rate of germination decline corresponds to the increase in the number of damaged grains (Figures 2a and $2 b)$. 


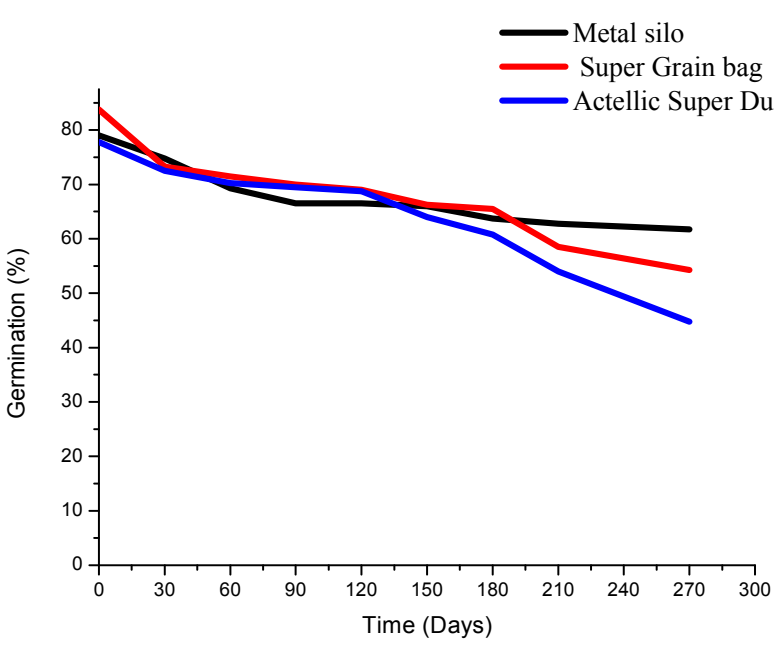

(a) Germination rate under artificial infestation

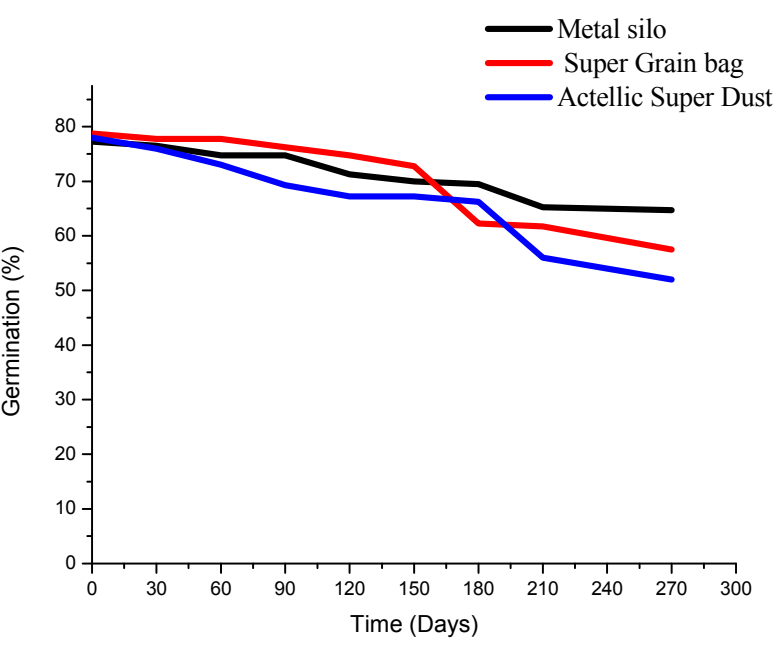

(b) Germination rate under natural infestation

Figure 2. Percentage germination of maize grain stored for 12 months in Malawi under artificial (a) and natural (b) infestations with Sitophilus zeamais and Prostephanus truncatus

\subsection{Number of Live and Dead Insects}

There were significant differences $(\mathrm{P}<0.05)$ in storage structures in mean number of live and dead $S$. zeamais and $P$. truncatus under both artificial and natural infestations (Table 2). The highest numbers of live and dead $S$. zeamais and $P$. truncatus were recorded for grain treated with Actellic super dust under both infestation methods. The least number of insects was recorded in grain stored in metal silo and the HB.

Table 2. Mean number of insects in maize stored for 12 months in metal silo, hermetic bag and maize treated with actelic dust under natural and artificial infestation with Sitophilus zeamais and Prostephanus truncatus in Malawi

\begin{tabular}{|c|c|c|c|c|c|c|c|c|}
\hline \multirow[b]{2}{*}{ Treatments } & \multicolumn{4}{|c|}{ Artificial infestation } & \multicolumn{4}{|c|}{ Natural infestation } \\
\hline & $\begin{array}{l}\text { No. Live } \\
\text { MW }\end{array}$ & $\begin{array}{l}\text { No. Dead } \\
\text { MW }\end{array}$ & $\begin{array}{l}\text { No. Live } \\
\text { LGB }\end{array}$ & $\begin{array}{l}\text { No. Dead } \\
\text { LGB }\end{array}$ & $\begin{array}{l}\text { No. Live } \\
\text { MW }\end{array}$ & $\begin{array}{l}\text { No. Dead } \\
\text { MW }\end{array}$ & $\begin{array}{l}\text { No. Live } \\
\text { LGB }\end{array}$ & $\begin{array}{l}\text { No. Dead } \\
\text { LGB }\end{array}$ \\
\hline Metal Silo & $1.74^{b}$ & $12.04^{\mathrm{b}}$ & $0.59^{\mathrm{c}}$ & $10.95^{b}$ & $0.07^{b}$ & $18.06^{\mathrm{b}}$ & $0.14^{\mathrm{b}}$ & $3.17^{\mathrm{a}}$ \\
\hline Hermetic bag & $2.37^{b}$ & $16.16^{\mathrm{b}}$ & $20.70^{\mathrm{b}}$ & $92.10^{\mathrm{a}}$ & $1.79^{\mathrm{a}}$ & $31.02^{\mathrm{b}}$ & $1.49^{\mathrm{ab}}$ & $3.57^{\mathrm{a}}$ \\
\hline Actellic dust & $4.71^{\mathrm{a}}$ & $34.69^{\mathrm{b}}$ & $116.64^{\mathrm{a}}$ & $100.75^{\mathrm{a}}$ & $2.34^{\mathrm{a}}$ & $60.53^{\mathrm{a}}$ & $9.42^{\mathrm{a}}$ & $5.11^{\mathrm{a}}$ \\
\hline SE & 2.62 & 5.50 & 47.36 & 18.82 & 1.44 & 8.39 & 0.68 & 4.27 \\
\hline
\end{tabular}

Note. Means followed by the same letter in a column are not significantly different $(\mathrm{P}<0.05)$. MW: maize weevil, Sitophilus zeamais; LGB: larger grain borer, Prostephanus truncatus.

\section{Discussion}

The study clearly showed that metal silo can effectively protect grain stored with minimum damage and weight loss. Kimenju and De Groote (2010) also reported that the metal silo has the lowest weight loss with or without insecticiede. Proctor (1994) also abserved that metal silos can be used to protect stored grain and reduce the amount of grain spoiled by rain exposure and pest penetration. The use of metal silo can help in higher quality long term storage reducing the cycles of surplus and scarcity in seasons or years. The use of small size metal silos for rural households has been proved successful in Swaziland and Bolivia by improving food security, reduced waste and maintenance the quality of the grain (http://12.000.scripts.mit.edu/mission2014/solutions/ food-storage-system-solar-dryers-metal-silos). The loss avoided by using metal silo in Kenya also resulted in a significantly higher economic gains (100 USD) after 12 months of storage (Kimenju \& De Groote, 2010). According to Food and Agriculture Organization of the United Nationa (FAO) (2008), metal silos not only prevent losses caused after storage but also other collatoral losses during production (labour, inputs, opportunity costs and unfulfilled expectaions). On the other hand, Actellic treated grain had suffered the highest damage and considarable insect infestation. These might be due to the loss of potency of the chemical ingredients after six months of storage an indication for the need for repeated application to achieve protection over a longer period. 
Grains stored in metal silo showed better germination followed by grains stored in HB; however, the least germination was observed in grains treated with Actelic Super kept in PPB. Insect pest damage is a major factor responsible for decline in quantity, quality and germination potential of stored seed (Olakojo \& Akinlosotu, 2004). Hosang et al. (2012) also reported that rate of germination varies with storage techniques used and in all treatments tested germination rates declines over time. Tekrony et al. (2005) also reported 50-80\% germination decline in maize stored in uncontrolled warehouse after eight months of storage. The low rate of germination in treated grains might be attributed to the high level of insect damage in storage, the original grain condition and variation in the rate of germination at the beginning of the experiment.

The high number of insect count in Actellic super dust treatment explains the high percentage weight loss and grain damage and low germination rate. The introduction of insects and presence of larger number of LGB in artificially infested grain had increased the insect pressure and resulted in more weight loss and grain damage. Hodges et al. (1983) reported that in the absence of LGB, maize typically loses $4-5 \%$ in nine months which might be increased to $10 \%$ in the presence of LGB. The magnitude of insect presence, live or dead, shows that there were insects with biological activities, completing their life cycle in the storage (Atui et al., 1998).

The present study showed that grain could be stored in the metal silos for a minimum of 12 month with weight loss of less than $5 \%$. Alternatively, hermetic bags can be used effectively for six months before it would be perforated by the LGB. The commonly used insecticide, Actelic Super, was able to control grain damage up to 150 days after storage. This indicates the need for repeated application of insecticides to achieve effective long term storage which incurs additional expense to farmers. The study also confirmed that metal silo and SGB can store grains with acceptable germination rate after 12 months of storage. Farmers with limited access and resource to invest on seed storage facilities and chemicals can use these structures to store their seed with reasonable rate of germination. Metal silo has also lowest number of maize weevil and LGB throughout the storage period. Metal silo and SGB are relatively affordable and pose no human or environmental risk so far. They are also an effective chemical free storage structures that can solve the storage pest problems at farm level. The use of such technologies plays a vital role to farmers in order to realize the benefits of improved agricultural technologies such as fertilizers and high yielding varieties. Hence, efforts should be made to improve access to these technologies to rural farmers at a reasonable price and credit arrangements that take in to consideration the level of production and marketing of maize at household level. However, hermetic storage technologies should not be viewed as single stand-alone structures to fight storage losses which occur at every level in the production cycle. Other improved post harvest management options such as timely harvesting, drying grain to optimum moisture content (12-13\%), proper shelling and cleaning of cobs and other practices that reduce initial deterioration of grain should also be promoted. Hence, introduction and promotion of small scale farm level harvesting, drying and threshing technologies can also contribute significantly to the efforts towards the fight against hunger. However, effective supply chain should be developed and promoted to improve access to these technologies.

\section{Conclusion}

Engagement of private sector mainly through training rural youth in manufacture and sell of metal silos and facilitating development of financial support for artisans and farmers. Capacity building and awareness creation at all levels on general post-harvest management practices and proper handling and use of these technologies should also be supported.

\section{Acknowledgements}

This work was supported by the Swiss Agency for Development and Cooperation.

\section{References}

Aberman, N., Meerman, J., \& Ben, T. (2015). Mapping the linkages between agriculture, food security \& nutrition in Malawi. International Food Policy Research Institute (IFPRI), Washington, DC, USA.

Adams, J. M., \& Schulter, G. M. (1978). Losses Caused by Insects, Mites and Micro-organisms. In K. L. Harris \& C. G. Lindblad (Eds.), Postharvest Grain Loss Assessment Methods (pp. 83-95). New York, American Association of Cereal Chemists.

Atui, M. B., Lázzari, F. A., \& Zamboni, C. Q. (1998). Efeito do processamento do milho em grão no nível de matérias estranhas encontradas no grits e fubá. Revista Instituto Adolfo Lutz, 57, 57-63.

Bezu, S., Kassie, T., Shiferaw, B., \& Ricker-Gilbert, J. (2014). Impact of Improved Maize Adoption on Welfare of Farm Households in Malawi: A Panel Data Analysis. World Development, 59, 120-131. https://doi.org/ 10.1016/j.worlddev.2014.01.023 
Blessings, C., (2012). The Political Economy of Agricultural Policy Processes in Malawi: A Case Study of the Fertilizer Subsidy Programme. FAC Working Paper 39. Brighton: Future Agricultures Consortium.

Farrell, G., \& Schulten, G. G. M. (2002). Larger grain borer in Africa: A history of efforts to limit its impact. Integrated Pest Management Reviews, 7, 67-84. https://doi.org/10.1023/A:1026345131876

Hodges, R. J., Dunstan, W. R., Magazini, I., \& Golob, P. (1983). An outbreak of Prostephanus truncatus (Horn) (Coleoptera: Bostrichidae) in East Africa. Protection Ecology, 5, 1983-194.

Hosang, E. Y., Sutherland, M. W., Dalgliesh, N. P., \& Whish, J. P. M. (2012). An alternative storage technique for maintaining maize seed quality in West Timor. $16^{\text {th }}$ Australian Agronomic Conference. Retrieved November 1, 2014, from http://www.regional.org.au/au/asa/2012/crop-production/7992_hosangey.htm

IFPRI (International Food Policy Research Institute). (2013). Assessment: Malawi agricultural market information system (p. 70). Washington, DC, USA.

Kimenju, S. C., \& De Groote, H. (2010). Economic Analysis of Alternative Maize Storage Technologies in Kenya. Contributed Paper presented at the Joint 3rd African Association of Agricultural Economists (AAAE) and 48th Agricultural Economists Association of South Africa (AEASA) Conference, Cape Town, South Africa, September 19-23, 2010.

Likhayo, P., Bruce, A. Y., Mutambuki, K., Tefera, T., \& Mueke, J. (2016). On-Farm Evaluation of Hermetic Technology against Maize Storage Pests in Kenya. Journal of Economic Entomology, 109, 1943-1950. https://doi.org/10.1093/jee/tow134

Maonga, B. B., Maganga, A. M., \& Kankwamba, H. (2015). Smallholder farmers' willingness to incorporate biofuel crops into cropping systems in Malawi. International Journal of Food and Agricultural Economics, 3, 87-100.

Olakojo, S. A., \& Akinlosotu, T. A. (2004). Comparative study of storage methods of maize grains in South Western Nigeria. African Journal of Biotechnology, 7, 362-365.

Phiri, N. A., \& Otieno, G. (2008). Report on managing pests of stored maize in Kenya, Malawi and Tanzania. Nairobi: The MDG Centre, East and Southern Africa.

Proctor, D. L. (1994). Grain storage techniques: Evolution and trends in developing countries. FAO Agricultural Services Bulletin No. 109 (Vol. 109). GASCA-Group for Assistance on Systems Relating to Grain after Harvest. Rome: Food and Agriculture organization of the United Nations.

Rees, D., Farrell, G., \& Orchard, J. (2002). Crop Post-harvest: Science and Technology. John Wiley \& Sons, London.

SAS. (2010). The SAS Statistical System, Version 9.2. SAS institute, Caryy, NC.

SDC (Swiss Agency for Development and Corporation). (2008). Latin America Section. Fighting Food Security with Metal Silo and Job Creation. Berne, Switzerland.

Tefera, T., Kanampiu, F., De Groote, H., Hellin, J., Mugo, S., Kimenju, S., ... Banziger, M. (2011). The Metal Silo: An effective grain storage technology for reducing post-harvest insect and pathogen losses in maize while improving smallholder farmers' food security in developing countries. Crop Protection, 30, $240-245$. https://doi.org/10.1016/j.cropro.2010.11.015

Tekrony, D. M., Shande, T., Rucker, M., \& Egli, D. B. (2005). Effect of seed shape on corn germination and vigour during warehouse and controlled environmental storage. Seed Science and Technology, 33, 185-197. https://doi.org/10.15258/sst.2005.33.1.19

World Bank. (2010). Missing Food: The case of post-harvest grain loss in sub-Saharan Africa. Report No. 60371-AFR. NW Washington, DC.

\section{Copyrights}

Copyright for this article is retained by the author (s), with first publication rights granted to the journal.

This is an open-access article distributed under the terms and conditions of the Creative Commons Attribution license (http://creativecommons.org/licenses/by/4.0/). 